\title{
Penyuluhan Hukum Tentang Pentingnya Memperoleh Sertifikat Halal Dalam Usaha Kuliner di Kabupaten Sumbawa
}

\author{
Cahyowati*, Galang Asmara, Rodliyah, Risnain \\ Fakultas Hukum Universitas Mataram
}

\begin{abstract}
Kata Kunci:
Penyuluhan

hukum,

Sertifikat halal,

Usaha kuliner
\end{abstract}

\begin{abstract}
Abstrak: Sertifikasi Halal menjadi sesuatu yang wajib dimiliki oleh sebuah usaha kuliner mengingat bahwa sebagian besar masyarakat Indonesia adalah Muslim yang sangat sensitif terhadap makanan haram. Pencantuman label halal sangat penting bagi kedua pihak, yaitu produsen dan konsumen.Adanya pencantuman label halal, konsumen lebih merasa aman dalam mengkonsumsi dan menggunakan produk atau makanan tersebut. Selain itu, konsumen juga mendapatkan jaminan bahwa produk tersebut tidak mengandung sesuatu yang tidak halal dan diproduksi dengan cara yang halal dan beretika. Desa Labuhan Bontong merupakan salah satu desa di Kecamatan Taruno Kabupaten Sumbawa yang terkenal dengan produk terasinya.Tujuan diadakannya penyuluhan hukum di Desa Labuhan Bontong untuk memberikan pengetahuan dan pemahaman tentang aturan memperoleh sertifikat halal dalam usaha kuliner, dan mendorong peserta penyuluhan untuk memiliki respons terhadap permasalahan yang dihadapi.Simpulan, masyarakat di Desa Labuhan Bontong Kecamatan Taruno belum pernah memperoleh penyuluhan hukum tentang memperoleh sertifikat halal dalam usaha kuliner sehingga mereka sangat senang memperoleh pengetahuan tersebut untuk meningkatkan kualitas dan daya saing produksi Terasi Empang. Permasalahan yang dihadapi masyarakat di Desa Labuhan Bontong adalah permasalahan modal, pemasaran, pembinaan, tempat memproduksi dan menyimpan terasi yang hieginis.
\end{abstract}

\section{Korespondensi: a.cahyowati@gmail.com}

\section{PENDAHULUAN}

Undang-Undang Dasar Negara Republik Indonesia (UUD) 1945 Pasal 29 ayat (2) mengatur negara menjamin kemerdekaan tiap-tiap penduduk untuk memeluk agamanya masing-masing dan untuk beribadat menurut agama dan kepercayaannya itu. Dalam penjelasan pasal tersebut, mengandung makna, negara hadir memberikan jaminan kebebasan, tiap tiap penduduk untuk melaksanakan ajaran agama dan kepercayaannya sesuai dengan norma dan/atau kaidah yang menjadi nilai atau aturan dasar agama yang di anut setiap warga negara.

Seiring dengan bertumbuhnya kesadaran kebutuhan produk dan jasa halal di Indonesia bahkan di dunia, sementara kebutuhan produk halal tidak hanya terbatas pada makanan saja juga meliputi segala aspek bidang kehidupan sosial masyarakat. ${ }^{1}$

Sektor dalam industri halal tersebut terdiri atas 10 sektor yang secara ekonomi dan bisnis berkontribusi besar dalam industry halal yaitu (industry makanan, perjalanan wisata, pakaian

${ }^{1}$ Merujuk ke konstitusi kita, Pasal 28E ayat (1) dan Pasal 29 ayat (1) dan ayat (2) Undang-Undang Dasar 1945 (UUD 1945) mutatis mutandis, Negara menjamin kemerdekaan tiap-tiap penduduk untuk memeluk agamanya masing-masing dan untuk beribadat menurut agamanya dan kepercayaannya itu. Begitu juga dengan penduduk muslim Indonesia, mereka memiliki hak konstitusional untuk memperoleh perlindungan hukum terhadap kehalalan produk sesuai dengan keyakinan agamanya. Oleh karena itu mereka perlu diberi perlindungan hukum berupa jaminan kehalalan pangan yang dikonsumsi dan produk lain yang digunakan 
dan fashion, kosmetik, financial, farmasi, media dan rekreasi, kebugaran, pendidikan dan seni budaya). ${ }^{2}$

Hal tersebut tidak bisa terlepas dari jumlah penduduk Muslim dunia yang terus mengalami pertumbuhan secara pesat, maka tentu membawa konsekuensi semakin besar kebutuhan akan jasa halal. Berdasarkan data Majelis Global, jumlah penduduk Muslim global pada 2012 sebanyak 1,8 miliar jiwa, pada 2030 diproyeksikan jumlah penduduk Muslim dunia mencapai 2,2 miliar jiwa. Dalam bidang konsumsi saja Indonesia menempati peringkat pertama sebagai konsumen terbesar produk halal pada sektor makanan dan minuman sebesar USD155 miliar. Penerapan manajemen rantai pasok halal sangat diperlukan untuk menjamin kualitas halalnya sebuah produk dan jasa. Penanganan produknya pun harus dipisahkan antara halal dengan tidak halal dan proses tersebut harus terjamin dari hulu hingga hilirnya. ${ }^{3}$

Selain perizinan usaha, sertifikasi Halal menjadi sesuatu yang wajib dimiliki oleh sebuah usaha kuliner mengingat bahwa sebagian besar masyarakat Indonesia adalah Muslim yang sangat sensitif terhadap makanan haram. Pencantuman label halal sangat penting bagi kedua pihak, yaitu produsen dan konsumen.

Dengan adanya pencantuman label halal, konsumen lebih merasa aman dalam mengkonsumsi dan menggunakan produk atau makanan tersebut. Selain itu, konsumen juga mendapatkan jaminan bahwa produk tersebut tidak mengandung sesuatu yang tidak halal dan diproduksi dengan cara yang halal dan beretika. Sedangkan bagi produsen, pencantuman label halal dapat membangun kepercayaan dan loyalitas konsumen terhadap produk tersebut. Produk yang bersertifikat halal memiliki keunggulan kompetitif dibandingkan dengan produk yang tidak mencantumkan label tersebut.

Sertifikasi halal adalah fatwa tertulis Majelis Ulama Indonesia (MUI) yang menyatakan kehalalan suatu produk sesuai dengan syariat Islam. Bentuk dari sertifikasi ini adalah dengan pencantuman label halal pada kemasan. Hal ini telah diatur dalam Ketentuan UU No. 33 Tahun 2014 tentang Jaminan Produk Halal. Untuk mendapatkan izin pencantuman logo halal, maka pemilik usaha (produsen) harus melakukan permohonan sertifikasi halal dengan serangkaian proses yang sudah diatur oleh lembaga MUI.

Desa Labuhan Bontong, merupakan salah satu desa dari 7 desa yang ada di Kecamatan Tarano. Desa ini terletak di Muara, umumnya masyarakat mempunyai mata pencaharian sebagai nelayan, dan istri nelayan mengolah rebon menjadi terasi. Terasi yang dihasilkan masyarakat di Desa labuhan Bontong dikenal sebagai Terasi Empang.

Berdasar hasil analisis situasi , maka dapat diidentifikasi permasalahan sebagai berikut:

1) Apakah masyarakat Sumbawa sudah pernah memperoleh sosialisasi mengenai Cara Memperoleh Sertifikat Halal dalam Usaha Kuliner?

2) Apa hambatan/kendala memperoleh sertifikat halal dalam usaha kuliner, dan upaya untuk mengatasinya.

${ }^{2}$ https://www.medcom.id , Ekonomi , analisa ekonomi, Safri Haliding Wakil Ketua Umum Masyarakat Ekonomi Syariah (MES) DKI Jakarta, Ketua Umum MGI Islamic Finance Forum \& CoFounder Zakpay.com 5 Februari 2019

${ }^{3}$ Ibid. 


\section{METODE KEGIATAN}

Metode yang digunakan dalam penyuluhan hukum adalah ceramah (dialog dua arah) antara tim penyuluh dan masyarakat. Persiapan sebelum penyuluhan hukum dilakukan adalah :

1. Menghimpun peraturan-peraturan yang berkaitan dengan sertifikasi halal, perlindungan konsumen, dan peraturan tentang pangan;

2. Menyiapkan hand out, agar penyuluhan hukum lebih terarah dan sistimatis sehingga penyampaian materi lebih mudah dipahami;

3. Menghimpun pertanyaan-pertanyaan dari peserta penyuluhan hukum dan memberikan jawaban atas pertanyaan yang diajukan. Proses penyuluhan hukum dan tanya jawab peserta digunakan sebagai bahan menulis laporan hasil pengabdian pada masyarakat., dan bahan pembelajaran di Program Doktor Ilmu Hukum (PSDIH).

\section{HASIL DAN PEMBAHASAN}

\section{A. Pengaturan Produk Halal}

Adanya pencantuman label halal, konsumen lebih merasa aman dalam mengkonsumsi dan menggunakan produk yang dihasilkan oleh produsen. sedangkan bagi produsen, pencantuman label halal dapat membangun kepercayaan dan loyalitas konsumen terhadap produk tersebut. Produk yang bersertifikat halal memiliki keunggulan kompetitif dibandingkan dengan produk yang tidak mencantumkan label tersebut. Pencantuman sertifikat Halal diatur dalam berbagai peraturan terkait, yaitu: UU 7 Tahun 1996 tentang Pangan dan Peraturan Pemerintah No.69 Tahun 1999 tentang Label dan Iklan pangan, UU No.8 Tahun 1999 tentang Perlindungan Konsumen, dan UU No.33 Tahun 2014 tentang Jaminan Produk Halal.

1) UU No.7 Tahun 1996 tentang Pangan

Jika dicermati aturan yangtercantum dalam UU No. 7 Tahun 1996 tentang Pangan dan Peraturan Pemerintah Nomor 69 Tahun 1999 Tentang Label dan Iklan Pangan, diketahui: a. ketentuan mengenai kehalalan sebuah produk cukup dengan keterangan bahwa produk tersebut halal. Keterangan itu dicantumkan sendiri oleh produsen. Hal itu Juga hanya bersifat fakultatif, bukan keharusan. b. tidak perlu ada lembaga khusus yang mensertifikasi produk halal. Produsen sendiri yang mencantumkan keterangan halal itu pada produknya. ${ }^{4}$

2) UU No.8 Tahun 1999 tentang Perlindungan Konsumen

Pemberian sertifikat halal dalam sebuah produk terkait juga diatur dala UU No.8 Tahun 1999, Undang-Undang ini dikeluarkan untuk melindungi konsumen mendapatkan kepastian atas barang dan/jasa yang diperoleh dari perdagangan. Perlindungan konsumen adalah segala upaya yang menjamin adanya kepastian hukum untuk memberi perlindungan kepada konsumen, sedangkan pengertian konsumen adalah setiap orang pemakai barang dan/atau jasa yang tersedia dalam masyarakat, baik bagi kepentingan diri sendiri, keluarga, orang lain, maupun makhluk hidup lain dan tidak untuk diperdagangkan. Tujuan

${ }^{4}$ Muh.Zumar Aminuddin, 2016, "Sertifikasi Produk Halal: Studi Perbandingan Indonesia dan Thailand”, Jurnal Shahih P2M IAIN Surakarta, Vol.1 No.1 Januari-Juni., hal29. 
Perlindungan Konsumen diatur dalam Pasal 3 UU No.8 Tahun 1999, diantaranya meningkatkan kesadaran, kemampuan dan kemandirian konsumen untuk melindungi diri, menghindari ekses negatif pemakaian barang dan / atau jasa, menuntut hak-haknya sebagai konsumen, Menumbuhkan kesadaran pelaku usaha mengenai pentingnya perlindungan konsumen sehingga tumbuh sikap yang jujur dan bertanggung jawab dalam berusaha, dan meningkatkan kualitas barang/jasa sehingga terjamin kesehatan, kenyamanan, keamanan, dan keselamatan konsumen. Hak dan kewajiban konsumen diatur dalam Pasal 4 dan Pasal 5 UU No.8 Tahun 1999, diantaranya: Hak atas kenyamanan, keamanan dan keselamatan dalam mengkonsurnsi barang dan/atau jasa.

Hak dan kewajiban pelaku usaha diatur dalam Pasal 6 dan Pasal 7 UU No.8 Tahun 1999, diantaranya: Hak untuk mendapat perlindungan hukum dari tindakan konsumen yang beritikad tidak baik, mendapatkan perlindungan hukum, melakukan pembelaan diri sepatutnya Hak untuk mendapat perlindungan hukum dari tindakan konsumen yang beritikad tidak baik, dalam melakukan kegiatan usahanya.

Larangan pelaku usaha diatur dalam Pasal 8 UU No.8 Tahun 1999,diantaranya: jika tidak memenuhi atau tidak sesuai dengan standar yang dipersyaratkan, tidak sesuai dengan berat bersih atau netto sebagaimana yang dinyatakan dalam label atau etiket barang, tidak sesuai dengan ukuran, takaran, timbangan, tidak sesuai dengan janji, tidak mencantumkan tanggal kadaluwarsa, dan tidak mengikuti ketentuan berproduksi secara halal sebagaimana dicantumkan dalam label.

3) UU No.33 Tahun 2014 tentang Jaminan Produk Halal

Proses pembahasan RUU tentang Jaminan Produk Halal merupakan perjalanan yang cukup panjang, dari periode DPR RI 2004- 2009 hingga DPR RI periode tahun 2014. Perjalanan panjang produk UU ini menunjukkan adanya vested interest dari kelompok agama, politisi dan pelaku bisnis. ${ }^{5}$ Perdebatan di kalangan politisi DPR tentang RUU ini pada dasarnya lebih bersifat formalistis prosedural, bukan pada aspek sosial kebutuhan masyarakat yang harus dijamin oleh negara dalam mendapatkan perlindungan produk. ${ }^{6}$

Praktek sertifikasi produk halal selama ini telah dilakukan Majelis Ulama Indonesia (MUI). Majelis Ulama Indonesia membentuk Lembaga Pengkajian Pangan Obat obatan dan Kosmetika Majelis Ulama Indonesia yang disingkat dengan LP POM MUI pada tanggal pada 6 Januari 1989 sebagai bagian dari upaya untuk memberikan jaminan bagi umat Islam terutama dalam mengkonsumsi pangan, obat-obatan dan kosmetika. ${ }^{7}$

\footnotetext{
${ }^{5}$ Moh.Mahfud,MD., Politik Hukum di Indonesia, Jakarta, 2011, Rajawali Press, hal 373

${ }^{6}$ Ibid

${ }^{7}$ tugas LP POM MUI: a. membuat dan mengembangkan standar system pemeriksaan halal, b.melakukan sertifikasi halal untuk produk-produk halal yang beredar dan dikonsumsi masyarakat c. mendidik dan menyadarkan masyarakat untuk senantiasa mengkonsumsi produk halal. d. memberikan informasi yang lengkap dan akurat mengenai kehalalan produk dari berbagai aspek. Lihat http://www.halalmui.org diakses tanggal 10 Mei 2013. Lihat juga Azmi Siradjuddin, "Regulasi Makanan Halal di Indonesia," dalam Jurnal Penelitian Ilmiah, Vol. 13 No. 1 (2013). Menjadi hak umat Islam untuk mendapatkan perlindungan kehalalan produk yang dikonsumsi mereka. MUI masih dilihat sebagai lembaga penting dalam proses ini.
} 
Proses untuk memperoleh sertifikat halal, sebagai berikut: ${ }^{8}$

1. Mendaftar ke sekretariat LPPOM MUI

2. Setelah formulir dikembalikan ke LP POM beserta kelengkapannya maka Tim auditor LP POM MUI akan melakukan audit ke lokasi produsen.

3. Hasil audit dan laboratorium akan dievaluasi dalam rapat uditor LP POM MUI. Jika memenuhi persyaratan maka akan dibuatkan laporan hasil audit yang selanjutnya diajukan pada Sidang Komisi Fatwa MUI untuk diputuskan status kehalalannya.

4. Sidang komisi fatwa MUI dapat menolak laporan hasil audit dan hasilnya akan disampaikan kepada produsen pemohon. Penolakan tersebut dikarenakan persyaratan yang telah ditentukan belum terpenuhi.

5. Sertifikat Halal baru akan dikeluarkan oleh Majelis Ulama Indonesia setelah ditetapkan status kehalalannya oleh Komisi Fatwa MUI.

6. Sertifikat Halal berlaku selama 2 (dua) tahun sejak tanggal penetapan fatwa.

7. Tiga bulan sebelum masa berlaku Sertifikat Halal berakhir, produsen harus mengajukan perpanjangan sertifikat halal sesuai dengan aturan yang telah ditetapkan LPPOM MUI.

Dari serangkaian proses tersebut diketahui, bahwa suatu produk yang dikatakan halal tidak semata-mata hanya terdiri dari penyediaan bahan-bahan baku pembuatan, tetapi juga pengolahan, penyimpanan, pengemasan, pendistribusian, penjualan, hingga penyajian. Pelaku usaha yang telah mendapatkan sertifikat halal sebaiknya segera mencantumkan label halal pada kemasan produk. Label halal harus ditempatkan di bagian yang mudah terlihat. Jika pelaku usaha tidak melakukan ketentuan tersebut, maka sanksi berupa pencabutan sertifikat halal pun akan dilakukan. Sama juga seperti halnya jika produsen yang telah mendapatkan sertifikat halal tapi tidak menjaga kehalalan dari produknya, maka sanksi berupa pidana penjara selama-lamanya 5 tahun dan denda sebanyak-banyaknya Rp 2 Miliar pun dapat dikenakan.

Perbandingan dengan Thailand mengenai sertifikasi halal, menurut Srawut Aree, deputy director Moslem Studies Chulalongcorn University, bahwa kepentingan ekonomilah yang mendorong pemerintah begitu bersemangat mendukung program-program yang berkaitan dengan sertifikasi halal. Menurut Prakorn Privakorn: a. 1 of alcoholic foods 10 world biggest food exporting countries b. 1 of 5 biggest countries exporting non-pork non- to OIC (with \& without Halal certified) c. Thai cuisine is top 5 with 3 recipes amongst top $10 \mathrm{~d}$. Top rank in world touristic destination e. Top medical hub in Asia for foreign patients and relatives. Dengan posisinya sebagai salah satu 10 negera-negara eksportir terbesar di dunia, mau tidak mau Thailand harus berhubungan dengan negara-negara muslim untuk kepentingan ekspornya. ${ }^{9}$

B. Pelaksanaan Sertifikasi Halal di Desa Labuhan Bontong

Dari hasil observasi di Desa Labuhan Bontong Kecamatan Tarano, Sosialisasi atau penyuluhan yang pernah diperoleh masyarakat di desa tersebut yang berkaitan dengan pengrajin terasi adalah penggunaan zat pewarna makanan dalam pembuatan terasi. Masyarakat di Desa Labuhan Bontong belum pernah memperoleh penyuluhan mengenai

\footnotetext{
${ }^{8}$ UU No.33 Tahun 2014 tentang Jaminan Produk Halal

${ }^{9}$ Muh.Zumar Aminuddin, Op.Cit, hal 35.
} 
sertikasi halal. Terasi yang diproduksi di desa Labuhan Bontong merupakan terasi yang terbuat dari rebon (udang kecil). Terasi rebon merupakan makanan yang masuk dalam kategori bumbu pembentuk rasa dan merupakan makanan khas yang sangat familiar bagi masyarakat Indonesia. ${ }^{10}$ Terasi dibuat dengan menggunakan tehnologi yang sangat sederhana. Sebagai bahan baku utama, udang rebon mudah diperoleh dan tersedia dalam jumlah yang berlimpah. Produk terasi yang mereka hasilkan masih sangat sederhana, terasi yang sudah dijemur, selanjutnya dicetak dalam cupuk (keranjang kecil anyaman daun lontarlihat foto). Pengrajin terasi di Desa Labuhan Bontong masih mengurus izin Pangan Industri Rumah Tangga (PIRT) pada Dinas Kesehatan.

C. Hambatan/Kendala Memperoleh Sertifikat Halal dalam Usaha kuliner, dan Upaya untuk Mengatasinya.

Pada saat penyuluhan hukum sesi tanya jawab, terungkap produksi terasi di Desa Labuhan Bontong, baru mengurus izin Pangan Industri Rumah Tangga (PIRT) pada Dinas Kesehatan. Proses pembuatan terasi dilakukan secara sederhana di masing-masing rumah atau dikenal dengan istilah home industri. Permasalahan yang dihadapi pengrajin terasi berkaitan dengan modal. Pemerintah daerah memberikan bantuan modal berkelompok untuk kepada pengrajin terasi, rencana penggunaan anggaran tersebut adalah untuk membuat gudang penyimpanan terasi yang lebih hieginis (lihat gambar), disamping itu mereka memerlukan pendampingan agar Terasi Empang dikemas dengan baik, sesuai yang diatur dalam Peraturan Pemerintah No. 69 Tahun 1999 tentang Label dan Iklan Pangan.Menurut peraturan ini pemberian label pada kemasan itu sifatnya wajib dan label tersebut harus mudah dilihat dan dibaca, tidak mudah rusak/luntur, dan tidak mudah lepas. Pada label wajib dicantumkan:

1. Nama produk, harus menunjukkan sifat atau keadaan yang sebenarnya dari produk tersebut

2. Komposisi/Bahan baku, merupakan keterangan dari bahan baku yang digunakan dalam produk pangan

3. Berat bersih/Isi bersih, merupakan berat produk pangan tanpa menyertakan berat kemasan

4. Nama dan alamat produsen, mencantumkan nama dan alamat pembuat produk

5. Waktu Kedaluwarsa, Kedaluwarsa merupakan keterangan yang berisi informasi kapan produk pangan itu tidak lagi layak untuk dikonsumsi,

6. Kode produksi, berisi keterangan mengenai riwayat produksi yang bersangkutan

7. Izin PIRT, izin Pangan Industri Rumah Tangga (PIRT) pada Dinas Kesehatan

8. Halal, melakukan pendaftaran di BPOM MUI di daerah masing-masing.

Dengan demikian, terasi produksi Desa Labuhan Bontong dapat memperoleh izin Pangan Industri Rumah Tangga (PIRT), memenuhi syarat kemasan/label yang baik, UU

\footnotetext{
${ }^{10}$ Sri Suro Adhawati, dkk, "Pengembangan Usaha Terasi Udang Rebon di Dusun Je’ne Desa Lagaruda Kecamatan Sanrobono Kabupaten Takalar”, http://journal.unhas.ac.id/index.php/panritaabdi/article/view/2625, diunduh Minggu 22-9-2019
} 
No.7 Tahun 1996 tentang Pangan, Pasal 3 UU No.8 Tahun 1999 tentang Perlindungan Konsumen, UU No.33 Tahun 2014 tentang Jaminan Produk Halal, pada akhirnya pengrajin terasi dapat mendaftarkan terasinya ke LPPOM MUI untuk memperoleh sertifikat halal,karena kewajiban sertifikasi halal mulai berlaku 17 Oktober 2019.

Untuk lebih jelasnya proses pembutan terasi di Desa Labuhan Bntong, sebagai berikut:

\section{Proses Pembuatan Terasi di Desa Labuhan Bontong-Kecamatan Tarano}
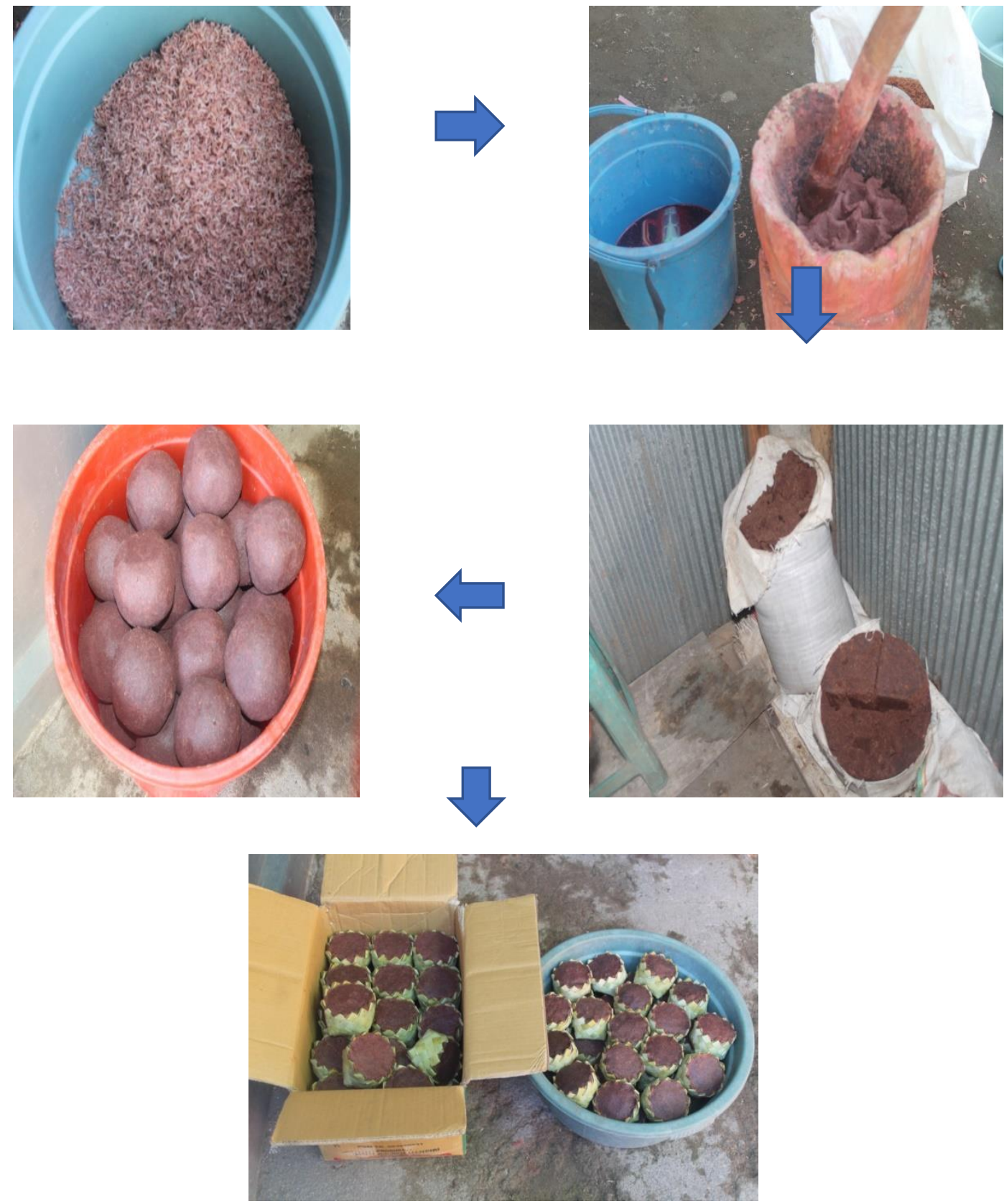

Keterangan Gambar:

1. Rebon sebagagai bahan pembuat terasi

2. Rebon ditumbuk dicampur air garam, dan pewarna makanan 
3. Terasi yang sudah dijemur, dimasukan karung dan disimpan di gudang penyimpanan

4. Terasi yang sudah ditimbang, dibentuk bulat dan ditimbang per $1 \mathrm{Kg}$

5. Dicetak ke dalam cupuk yang terbuat dari daun lontar, siap untuk dipasarkan.

\section{KESIMPULAN DAN SARAN}

Kesimpulan:

1. Masyarakat di Desa Labuhan Bontong Kecamatan Taruno belum pernah memperoleh penyuluhan hukum tentang memperoleh sertifikat halal dalam usaha kuliner sehingga mereka sangat senang memperoleh pengetahuan tersebut untuk meningkatkan kualitas dan daya saing produksi Terasi Empang

2. Permasalahan yang dihadapi masyarakat di Desa Labuhan Bontong adalah permasalahan modal, pemasaran, pembinaan, tempat memproduksi dan menyimpan terasi yang hieginis.

Saran:

Pemerintah Daerah Kabupaten Sumbawa perlu melakukan sosialisasi berkaitan dengan kemasan/labeling pada pengrajin terasi, agar terasi yang dihasilkan mempunyai kemasan yang menarik, dan memfasilitasi mereka memperoleh sertikat halal

\section{UCAPAN TERIMA KASIH}

Ucapan terima kasih disampaikan kepada Rektor Universitas Mataram, Ketua LPPM Universitas Mataram, dan Dekan Fakultas Hukum Universitas Mataram yang telah memfasilitasi sehingga kegiatan Pengabdian Pada Masyarakat dapat terselenggara, Kepala Desa Labuhan Bontong-Kecamatan Tarano, dan masyarakat yang telah berpartisipasi pada penyuluhan hukum.

\section{DAFTAR PUSTAKA}

Buku:

Moh.Mahfud,MD.,2011, Politik Hukum di Indonesia, Rajawali Press,Jakarta Jurnal/Makalah:

Azmi Siradjuddin, 2013“Regulasi Makanan Halal di Indonesia,” dalam Jurnal Penelitian Ilmiah, Vol. 13 No. 1.

Muh.Zumar Aminuddin, 2016, "Sertifikasi Produk Halal: Studi Perbandingan Indonesia dan Thailand" , Jurnal Shahih P2M IAIN Surakarta, Vol.1 No.1 Januari-Juni., hal29.

Sri Suro Adhawati, dkk, "Pengembangan Usaha Terasi Udang Rebon di Dusun Je'ne Desa Lagaruda Kecamatan Sanrobono Kabupaten Takalar”, http://journal.unhas.ac.id/index.php/panritaabdi/article/view/2625, diunduh Minggu 22-92019

Peraturan Perundang-undangan:

UUD NRI Tahun 1945 
UU No.7 Tahun 1996 tentang Pangan

UU No.8 Tahun 1999 tentang Perlindungan Konsumen,

UU No.33 Tahun 2014 tentang Jaminan Produk Halal.

Peraturan Pemerintah Nomor 69 Tahun 1999 Tentang Label dan Iklan Pangan. Internet:

https://www.medcom.id > Ekonomi > analisa ekonomi, Safri Haliding Wakil Ketua Umum Masyarakat Ekonomi Syariah (MES) DKI Jakarta, Ketua Umum MGI Islamic Finance Forum \& Co-Founder Zakpay.com 5 Februari 2019

http://www.halalmui.org diakses tanggal 10 Mei 2013 